\title{
Impact of Internal Branding (IB), Brand Commitment (BC) and Brand Supporting Behavior (BSB) on Organizational Attractiveness (OA) and Firm Performance(FP).
}

\author{
Neerja Kashive \\ Assistance Professor, VES's Institute of Management Studies and Research \\ 495-497, Near Municipal School, Collector's Colony, Chembur, Mumbai-400074 \\ E-mail: nirja.kashive@ves.ac.in
}

Vandana Tandon Khanna

Associate Professor, K.J Somaiya Institute of Management Studies \& Research

Vidyanagar vidyavihar, Mumbai-400077

E-mail: vandanat@somaiya.edu

Received: April 6, 2017 Accepted: April 19, 2017 Online published: April 25, 2017

doi:10.5296/ijhrs.v7i2.11113

URL: https://doi.org/10.5296/ijhrs.v7i2.11113

\begin{abstract}
This paper explores the various dimension of Internal Branding like training, orientation and briefing and its impact on Brand commitment and Brand supporting behavior (like brand allegiance, brand endorsement and brand citizen behaviour).The study shows that training, orientation and briefing of Internal Branding (IB) does impact Brand commitment(BC) and brand supporting behavior(BSB). Internal Branding impact both organizational attractiveness and Firm performance while brand commitment only impact organizational attractiveness. With respect to brand supporting behaviour, brand citizen behaviour (BCB) and brand allegiance (BA) impact Organization attractiveness, while brand citizen behaviour (BCB) and brand endorsement (BE) impact firm performance.

Keywords: Employee Branding, Employee Branding Equity, Internal Branding(IB), Brand commitment(BC) and Brand supporting behaviour (BSB), brand citizen behaviour(BCB), brand allegiance(BA), brand endorsement(BE), Organization attractiveness(OA).
\end{abstract}




\section{Introduction}

Internal branding has recently been identified as an enabler of an organisation's success in delivering the brand promise to fulfil customers' brand expectations decided by various communication activities (Drake et al., 2005). Many authors (Boone, 2000; Buss, 2002) have studied the steady growth of internal branding's popularity among companies such as Southwest, Sears, BASF, IBM and Ernst and Young. These examples shows the power of an informed workforce committed to delivering the brand promise. Most of the studies focused on the perspective of management and consultants while employees are considered targeted internal audience of an internal branding efforts. While some studies have provided empirical evidence for the association between internal branding and employees' brand commitment (Burmann and Zeplin, 2005), few have focused on the relationship between internal branding and employees' brand loyalty (Papasolomou and Vrontis, 2006a, b).

Being a member of an organisation having a strong employer brand inceases their self-esteem and create strong organisational identification (Lievens et al., 2007). Constant delivery of the brand promise create more trust and loyalty ensuring a steady supply of applicants (Holliday, 1997) and maintains high commitment and high performance in employees by ensuring the organisation's credibility (Burack et al., 1994). It attracts the right talent with the culture fit and at the same time provided the prospective employees an assurance of the work experience as expected by them (Bhatnagar and Srivastava, 2008). Further it helps in building stronger psychological contract with the employees so that they become the brand advocate of the company. "On-brand behaviours" among employees should be encouraged by marketing and explaining the brand internally (Mitchell, 2002). There is a need to manage employee behaviour so that it is consistent with the company's desired brand positioning (Henkel et al., 2007). Thus corporate brand or reputation management has been conceptualised as "living values internally and promoting those same values externally" (Davies et al., 2004).

This study aims to understand the internal branding from the employees' perspective; it will empirically assess the relationship between internal branding and employees' perception about organization attractiveness and firm performance as well as the relationships among different brand attitudes (i.e. brand commitment, and brand supporting behaviour). To achieve its objectives, a quantitative survey conducted with 350 employees from major IT companies was carried out.

\section{Literature Review}

\section{a) Employee Brand and Employee Brand Equity}

The employee brand has been defined as "the image presented to an organization's customers and other stakeholders through its employees" (Mangold and Miles, 2007: 77). This image can be either negative or positive, and depends upon the extent to which employees know and understand the desired brand image and are motivated to project that image to organizational constituents. King and Grace (2009) introduced the idea of employee-based brand equity and postulated that it impacts consumer-based brand equity as well as financial-based brand 
equity. Two critical elements are necessary in order to provide the competitive advantage an employee brand can provide to the employees (Miles and Mangold, 2005). First, employees must know and understand the desired brand image and they must be motivated to engage in the behaviors that are necessary to deliver the desired brand image. The extent to which psychological contracts are upheld in employees' minds impacts their desire to deliver the organization's expected brand image (Mangold and Miles, 2007). The extent to which these message systems send consistent messages determines the strength and nature of the employee brand (Greene et al., 1994; Mitchell, 2002; Robinson, 1996).

\section{b) Internal Branding}

According to Foster et al. (2010) the main focus of internal branding is on how the employees within an organization adopt the brand concept and live up to the promises that the brand should deliver to its external stakeholders. Thus the aim is to teach and communicate the brand values to employees (Foster et al., 2010; Backhaus \& Tikoo, 2004; Punjaisri et al.,2009). Punjaisri et al. (2009) says that internal branding can positively affect how employees identify with the brand. Mosley (2007) suggest that internal branding is about shaping the perceptions that employees have about the brand. It is suggested that there is a clear link between corporate branding and internal branding (Punjaisri \& Wilson, 2011, Foster et al., 2010). According to Foster et al. (2010) internal branding can, along with employer branding, be seen as developments or extensions of corporate branding. Kotler et al. (2009); Knox \& Freeman (2006) and de Chernatony \&McDonald (2003) agrees that everyone in an organization needs to "live the brand" to achieve complete success.

According to Punjaisri et al.(2009) the quality of a service and the deliverance of brand promises are ultimately dependent on the employees who come into direct contact with consumers. Maxwell \& Knox, (2009) argue that employer branding is an effective way of pursuing that employees' attitudes and behavior are in alliance with the corporate brand. Kimpakorn \& Tocquer (2009) further suggest that when the brand values are communicated in a good way to employees it is likely that they become committed to the brand and behave in accordance with organization's values. Thus according to Foster et al. (2010) employer branding can help organizations to attract the right employees that possesses values that matches a corporate brand.

Wallace and de Chernatony (2009) promote leadership as a condition for employees to live the brand, while Punjaisri et al. (2008) have more functional approach, promoting internal communication and HR training as being key mechanisms in the internal brand process. Burmann et al. (2009) incorporate internal communication, HR practices and leadership as determining factors of employee brand commitment. The internal brand management seeks to internalise the brand so that employees are more prepared to fulfil the explicit and implicit promises inherent in the brand (Berry, 2000; Miles and Mangold, 2004).According to King and Grace(2012)organization socialization, relationship orientation and receptiveness are three important internal branding factor which affect brand commitment. Corace (2007) believes that ultimately, treating employees with respect and dignity is what will lead to distinct behaviours (i.e.brand citizen behaviour).Strong relationships between the 
organisation and the employee are believed to be an instrumental in increasing employee job motivation (Bell et al., 2004) as the organisation-employee relationship is considered by employees to be an important, if not the most important, aspect of the working environment (Herington et al., 2009).

\section{c) Brand Commitment (BC)}

As internal branding aims at forming a shared understanding of a brand across the entire organisation, recent studies have shown its positive influence on employees' brand commitment (Punjaisri and Wilson, 2007). Papasolomou and Vrontis(2006)) have seen that internal branding influences employees' brand loyalty or their willingness to remain with the brand (Reichheld, 1996).Organisation identification (OI) theory focuses on the cognitive approach, the organisation commitment (OC) theory talks more of the emotional connections (Edwards, 2005). Thus, OC is considered as staff's emotional attachment to the organisation (Meyer and Allen, 1991; Meyer et al., 2002). Furthermore, it is noted that brand identification leads to employees' brand commitment (Burmann and Zeplin, 2005; Cheney and Tompkins, 1987) and commitment a key precursor to loyalty (Brown and Peterson, 1993; Pritchard et al., 1999; Reichers, 1985).

If the employee perceives the relationship with the organisation to be a positive and worthy of maintaining, then the employee has a high level of commitment to the organisation. Therefore commitment, is considered to be a key variable in determining organisational success (Morgan and Hunt, 1994) as employees feeling of belonging influences their choice to go above and beyond the job in order to achieve the organisation's goals (Castro et al., 2005). Castro et al. (2005) believe that commitment results in employees willing to make extra effort on behalf of the organisation. Thus Castro et al. (2005) suggests that performance of employees within their work environment is a significant reason for organisational commitment. Hence employees, who are satisfied with their work environment tend to, or have a desire to, reciprocate (Wayne et al., 1997; Castro et al., 2005). Through their perception of fairness (Deluga, 1994) and support from the organization (Wayne et al., 1997), employees shows behaviours that are beyond the formally expected requirements of their job (Deluga, 1994; Beckett-Camarata et al., 1998). Such behaviours, identified as brand citizenship behaviour, are employee behaviours which are non-prescribed or "above and beyond the norm", yet alinged with the brand values of the organisation, thus engendering positive organisational outcomes. Burmann et al. (2009) believe that the key determinants of brand strength as a result of internal brand management practices are brand commitment (BC) and brand citizenship behaviours (BCB). Brand commitment, is the psychological attachment or the feeling of belonging an employee has towards an organisation.

\section{d) Brand supporting behavior(BSB)}

The aim of internal brand management is to align individual employee behaviour with a desired brand identity( Tosti and Stotz, 2001 ).In conceptualising employee behavioural loyalty, a one dimensional approach such as employee satisfaction, employee engagement or employee turnover is believed to lack holistic insight. For this reason, Zeithaml et al (1996) believe that behavioural loyalty can manifest in many ways (for example, positive word of 
mouth, repeat patronage, greater spend). According to King and Grace (2012) indicators like employee satisfaction may be linked to behaviour, which are either historically based or, at best, only a rough indicator of future positive and productive employee behaviour. A measure of employee future-oriented thinking which shows his / her relationship with the brand i.e brand related behaviour is considered to provide for a more robust organisational measure. Henkel et al 's (2007, p. 311) conceptualise behavioural branding ' as any type of verbal and non-verbal employee behaviour that directly or indirectly determines brand experience and brand value'. Furthermore, Bloemer and Odekerken-Schr ö der (2006) identify several behavioural attributes that, holistically provides the conceptual richness of employee loyalty. These include an employee's proactive external communication about the organisation's brand, as well as the employee's positive desire to maintain a working relationship with the brand in the future. In addition to retention and positive word of mouth, Morhart et al (2009) identify participation and 'in-role', or brand compliant, behaviour as being appropriate measures of employee brand behaviour.

\section{i) Brand Endorsement $(B E)$}

Employee external promotion or communication of the brand to others is considered to be another important aspect of brand supporting behaviour. Brand endorsement can be defined as the extent to which an employee is willing to say positive things about the organization (brand) and to readily recommend the organisation (brand) to others. Shinnar et al (2004, p. 273) encourages the idea that employees who hold a favourable image towards their organisation are intrinsically motivated to provide positive external communication. Employee activity not only derives benefits for the employee. An employee's personal advocacy leads to positive organisational outcomes or such as increased recruitment cost efficiencies (Morehart, 2001), greater employee performance (Kirnan et al, 1989) and greater pre-employment knowledge (Williams et al, 1993) which subsequently impacts organisational socialisation. Brand endorsement is thus leads to significant organisational benefits as a result of employees having better brand knowledge.

\section{ii) Brand Allegiance(BA)}

Employee brand allegiance (or purchase intentions in a consumer context) is defined as the future intention of employees to continue with the organisation (brand). This intention is considered to be a crucial decision, given the significant economic impact caused for losing knowledgeable employees (Ramlall, 2004). This also helps in developing crucial human capital, whereby employees are considered to possess skills experience and knowledge which creates economic value for organisations through increased productivity (Snell and Dean, 1992). By retention of productive employees who constantly exhibit brand-related behaviours, service brand success is likely to be enhanced. This is so because the service brand promise is consistently delivered in a cost-effective and efficient manner. According to Punjaisri and Wilson (2007), an employee's intention to stay with the organisation is reflective of their awareness of the need to live up to the brand standards. This future-orientated thinking has been realized in the theory of reasoned action, which suggests that the best predictor of future behaviour is the intention to act (Schiffman et al , 2001). 
iii) Brand Citizenship Behavior(BCB)

Employees who are satisfied with their work environment tend to exhibit behaviours that are beyond the requirements of their job ( Beckett-Camarata et al ,1998 ). Such behaviours i.e brand consistent behaviour, can be defined as an employee behaviour that is often non-prescribed, yet consistent with the brand values of the organisation( Burmann et al , 2009 ). The significance of brand-supporting behaviour is that it is discretionary ( Castro et al, 2005 ), yet considered to be vital for organisational productivity ( Deluga, 1994 ). Brand consistent behaviour, or brand citizenship behaviour as coined by Burmann and Zeplin (2005), is considered to be ' the pivotal(behavioural) constituent for successful internal brand management ' ( Burmann et al , 2009, p. 266 ). Burmann and Zeplin (2005) believe there to be little difference with respect to brand-related behaviour in contrast to organisational-related behaviour. They suggest a modified concept to organisational citizenship behaviour (OCB), namely brand citizenship behaviour (BCB). Burmann and Zeplin (2005) believe such a modification is needed given that OCB is "considered" to have an internal focus while BCB have external focus. .

\section{e) Organizational Attractiveness}

A closely related concept to 'employer branding' is the concept of 'employer attractiveness'. This concept has been widely studeies in the areas of vocational behaviour (Soutar \& Clarke 1983), management (Gatewood et al. 1993), applied psychology (Jurgensen 1978; Collins \&Stevens 2002), communication (Bergstrom et al. 2002) and marketing (Ambler \& Barrow 1996; Gilly \& Wolfinbarger 1998; Ambler 2000; Ewing et al. 2002). Berthon et, al (2005) defined 'employer attractiveness' as the envisioned benefits that a potential employee sees in working for a specific organisation.Some studies that have studies potential applicants' attraction in initial recruitment stages have confirmed that organizational attraction is affected by applicants' perceptions of job or organizational characteristics such as pay, opportunities for advancement, location, career programmes, or organizational structure (Cable \& Graham, 2000; Highhouse et al., 1999; Honeycutt \& Rosen, 1997; Lievens, Decaesteker,Coetsier, \& Geirnaert, 2001; Lievens \& Highhouse, 2003; Turban \& Keon, 1993). Many authors have suggested that decisions to apply to an organization are often heavily rely on the general impression of applicants about the company's overall attractiveness (e.g.Belt \& Paolillo,1982; Fombrun \& Shanley, 1990; Rynes, 1991).

Recommendation intentions are defined (Van Hoye, 2008) as the extent to which employees have intention to recommend their organization as an employer to others. Thus word of mouth, as a recruitment source, is an significant predictor of organizational attractiveness (e.g., Van Hoye, 2012) and has a better impact on post hire outcomes like job satisfaction, performance and chances to quit (Breaugh \& Starke, 2000; Zottoli \&Wanous, 2000). These positive consequences may be due to the reason that word of mouth provides realistic and credible information (e.g., Cable \& Turban, 2001). Having ambassadors as the employees might thus be valuable for organizations in order to attract, recruit and motivate potential and current employees. If research has studied the consequences of recommendation intentions, what motivates employees to provide favorable word of mouth has been studied further 
(Shinnar, Young, \& Meana, 2004). Van Hoye (2008) has shown that a favorable image of an organization as an employer leads employees to recommend their organization. Van Hoye (2008) found that enhancing employees' perceptions of employer image is an effective way to increase their likelihood to recommend their employer to others.

\section{f) Firm Performance}

According to Fulmer et al., (2003) study, the time and money spent to create and support positive employee relation turned out to be worthwhile investment. As positive reputation tent to be stable and difficult to copy, they provide unique and sustainable competitive advantage for companies (Robert \& Dowling, 2002) Thus ,despite the additional cost incurred to provide employee friendly practices, the benefits are more than to compensate for the cost (Fulmer et al., 2003). Thus developing positive employee relations is no easy task, but those firms who are making continuous efforts and making investment will not likely to regret in near future (Romero, 2004). Through content analysis of website of Fortune's 100 best companies, Joyce (2003), argued that" these companies are distinguished by employee development programs, diversity initiatives, and fun work environment" (p.77).

Companies included on Fortune's 100 best companies list have higher market values and better return than matched firm not included on the list (Ballou et al., 2003; Fulmer et al., 2003). The market values of firm ranked in top one third of the list were higher than firms ranked in the bottom one third of the list (Ballou et al., 2003). Fulmer et al., (2003) showed that positive employee relation are beneficial for companies and may be related to improved performance (as measured by both accounting and market data: ROA and market-to-book value ratios). Being a best employer is a strong marketing or employer branding tool, signaling its favorable work environment publicly, which leads to attraction and retention of talent (Joyce, 2003).

\section{Research Methodology}

The questionnaire was administered on 350 employees of IT companies and 244 have filled it. Thus the respondent rate was $69.71 \%$.The companies were chosen on the basis of NASSCOM top 20 IT-BPM employers in India 2014-15.Thus IT companies included mix of companies with very good reputation, with medium reputation and with not so good reputation. Thus the sample provided the mix of companies having different reputation. Demographic details of the respondents with respect to the age, gender, qualification and work experience were collected.

\section{Questionnaire:}

Internal branding(IB) was measured by Punjaisri et al, (2009) having training with 4 items, orientation with 4 items, briefing with 2 items and brand identification with 5 items. Brand Commitment (BC) was measured by 5 items from King and grace (2012) scale. Brand Supporting Behaviour (BSB) was be measured by King et, al.(2012), 12 item scale having (i) brand endorsement (BE),(ii) brand consistent behaviour (BCB) and (iii)brand allegiance (BA). Organizational attractiveness (OA) was measured by three items adapted from the measure of perceived organizational attractiveness proposed by Highhouse, Lievens, and Sinar (2003). 


\section{Macrothink}

International Journal of Human Resource Studies

ISSN 2162-3058 2017, Vol. 7, No. 2

Respondents will rate these items on a 5-point rating scale, ranging from $1=$ strongly disagree to $5=$ strongly agree. Firm Performance (FP) was measured by scale adopted from Chun (2001b).

Reliabilities were tested for all the scales. It is seen that reliability for Internal Branding (IB) is 0.905, Brand Commitment (BC) is 0.883, Brand Supporting Behaviour (BSB) is 0.885, Organization attractiveness(OA) is 0.924 and Firm Performance(FP) is 0.817.

Internal Branding (IB)

Reliability Statistics

\begin{tabular}{|r|r|}
\hline $\begin{array}{c}\text { Cronbach's } \\
\text { Alpha }\end{array}$ & N of Items \\
\hline .905 & 10 \\
\hline
\end{tabular}

Item Statistics

\begin{tabular}{|l|r|r|r|}
\hline & Mean & Std. Deviation & $\mathrm{N}$ \\
\hline Training1 & 2.20 & 1.202 & 244 \\
Training2 & 2.58 & .779 & 244 \\
Training3 & 2.62 & .946 & 244 \\
Training4 & 2.00 & .880 & 244 \\
Orientation1 & 2.00 & .793 & 244 \\
Orientation2 & 2.82 & 1.040 & 244 \\
Oreintation3 & 2.51 & .949 & 244 \\
Orientation4 & 2.43 & 1.046 & 244 \\
Briefing1 & 2.34 & .913 & 244 \\
Briefing2 & 2.72 & 1.016 & 244 \\
\hline
\end{tabular}

Brand commitment (BC)

Reliability Statistics

\begin{tabular}{|r|r|}
\hline $\begin{array}{l}\text { Cronbach's } \\
\text { Alpha }\end{array}$ & N of Items \\
\hline .883 & 5 \\
\hline
\end{tabular}

\begin{tabular}{|l|r|r|r|}
\hline & \multicolumn{3}{|c|}{ Item Statistics } \\
\hline Bean & Std. Deviation & \multicolumn{1}{c|}{$\mathrm{N}$} \\
\hline Brandcomm1 & 2.25 & 1.287 & 244 \\
Brandcomm2 & 1.95 & .837 & 244 \\
Brandcomm3 & 2.24 & .904 & 244 \\
Brandcomm4 & 2.35 & .893 & 244 \\
\end{tabular}


Brand Supporting Behavior (BSB)

Reliability Statistics

\begin{tabular}{|r|r|}
\hline $\begin{array}{l}\text { Cronbach's } \\
\text { Alpha }\end{array}$ & N of Items \\
\hline .885 & 14 \\
\hline
\end{tabular}

\begin{tabular}{|l|r|r|r|}
\hline & Item Statistics \\
\hline & \multicolumn{1}{|c|}{ Mean } & Std. Deviation & \multicolumn{1}{c|}{$\mathrm{N}$} \\
\hline Brandendorse1 & 2.44 & .856 & 244 \\
Brandendorse2 & 2.09 & .673 & 244 \\
Brandendorse3 & 1.73 & .951 & 244 \\
Brandendorse4 & 2.09 & .739 & 244 \\
BCB1 & 2.29 & .806 & 244 \\
BCB2 & 2.49 & .891 & 244 \\
BCB3 & 2.24 & 1.142 & 244 \\
BCB4 & 2.35 & .845 & 244 \\
BCB5 & 2.16 & .956 & 244 \\
BCB6 & 2.39 & 1.062 & 244 \\
BA1 & 2.11 & 1.000 & 244 \\
BA2 & 2.41 & .849 & 244 \\
BA3 & 2.59 & .867 & 244 \\
BA4 & 2.61 & .978 & 244 \\
\hline
\end{tabular}

Organization attractiveness (OA)

Reliability Statistics

\begin{tabular}{|r|r|}
\hline $\begin{array}{c}\text { Cronbach's } \\
\text { Alpha }\end{array}$ & N of Items \\
\hline .924 & 3 \\
\hline
\end{tabular}

Item Statistics

\begin{tabular}{|l|r|r|r|}
\hline & \multicolumn{1}{|c|}{ Mean } & \multicolumn{1}{|c|}{ Std. Deviation } & \multicolumn{1}{c|}{$\mathrm{N}$} \\
\hline OA1 & 2.17 & 1.231 & 244 \\
OA2 & 2.38 & 1.117 & 244 \\
OA3 & 2.27 & 1.235 & 244 \\
\hline
\end{tabular}

Firm Performance (FP)

Reliability Statistics

\begin{tabular}{|r|r|}
\hline $\begin{array}{l}\text { Cronbach's } \\
\text { Alpha }\end{array}$ & N of Items \\
\hline .817 & 3 \\
\hline
\end{tabular}




\begin{tabular}{|l|r|r|r|}
\hline & \multicolumn{3}{|c|}{ Item Statistics } \\
\hline Fean & Std. Deviation & \multicolumn{1}{|c|}{$\mathrm{N}$} \\
\hline FP2 & 2.64 & .947 & 244 \\
FP3 & 2.37 & 1.239 & 244 \\
\hline
\end{tabular}

Item-Total Statistics

\begin{tabular}{|r|r|r|r|r|}
\hline & $\begin{array}{c}\text { Scale Mean if Item } \\
\text { Deleted }\end{array}$ & $\begin{array}{c}\text { Scale Variance if Item } \\
\text { Deleted }\end{array}$ & $\begin{array}{c}\text { Corrected Item-Total } \\
\text { Correlation }\end{array}$ & $\begin{array}{c}\text { Cronbach's Alpha if Item } \\
\text { Deleted }\end{array}$ \\
\hline FP1 & 4.39 & 3.737 & .708 & .720 \\
FP2 & 4.66 & 2.653 & .752 & .679 \\
FP3 & 5.02 & 4.123 & .598 & .820 \\
\hline
\end{tabular}

\section{Results}

Demographic details of the respondents shows that $42.2 \%$ are in age group of $20-25,32.0 \%$ are in age group of $26-30,7.4 \%$ in $31-35,15.2 \%$ in 36-40 and 3.3\% in above 40 years .With respect to gender $47.5 \%$ are female and $52.5 \%$ are male. $35.7 \%$ are in Junior level, $46.7 \%$ are in middle level and $17.6 \%$ are in senior level with respect to their designation. With respect to total years of experience $19.3 \%$ have above 10 years, $28.7 \%$ have between 5 to 10 years, $44.3 \%$ have between 1 to 5 years, $7.0 \%$ have less than 1 year and $0.8 \%$ have no prior experience. When asked how many years have they spend in current organization. $14.3 \%$ have spent above 10 years, $19.7 \%$ between $7-9$ years,7.8\% between $4-6$ years, $40.6 \%$ between 1-3 years and $17.6 \%$ have spent less than a year in the present organization they are working for.

H1: Training, Orientation and Briefing have positive effect on Brand commitment (BC).

Table 1 shows the regression analysis with dependent variable Brand commitment (BC) and component of Internal Branding (IB) i.e Training, Orientation and Briefing as independent variables. The regression model is significant $(p<0.01)$ with adjusted $R$-square value of 0.751 . Training, Orientation and Briefing all have a significant $(\mathrm{p}<0.05)$ impact on dependent variable with std coefficient beta values of $0.222,0.273$ and 0.435 respectively.

Table 1. Regression analysis with dependent variable Brand commitment (BC) and component of Internal Branding (IB) i.e Training, Orientation and Briefing as independent variables.

\begin{tabular}{|c|c|c|c|c|c|}
\hline \multicolumn{6}{|c|}{ Coefficients $^{a}$} \\
\hline \multirow[t]{2}{*}{ Model } & \multicolumn{2}{|c|}{ Unstandardized Coefficients } & \multirow{2}{*}{$\frac{\text { Standardized Coefficients }}{\text { Beta }}$} & \multirow[t]{2}{*}{$\mathrm{t}$} & \multirow[t]{2}{*}{ Sig. } \\
\hline & $B$ & Std. Error & & & \\
\hline (Constant) & -.228 & .097 & & -2.348 & .020 \\
\hline Training & .272 & .076 & .22 & 3.595 & .000 \\
\hline Orientation & .302 & .078 & .27 & 3.892 & .000 \\
\hline Briefing & .413 & .053 & .43 & 7.762 & .000 \\
\hline
\end{tabular}

a. Dependent Variable: Brand Commitment 
H2: Internal Branding (IB) have positive effect on Brand commitment (BC).

Table 2 shows the regression analysis with dependent variable Brand commitment (BC) and Internal Branding (IB) as independent variables. The regression model is significant $(\mathrm{p}<0.01)$ with adjusted R-square value of 0.751. Internal Branding (IB) have a significant $(\mathrm{p}<0.05)$ impact on dependent variable with std coefficient beta values of 0.867 .

Table 2. Regression analysis with dependent variable Brand commitment (BC) and Internal Branding (IB) as independent variables

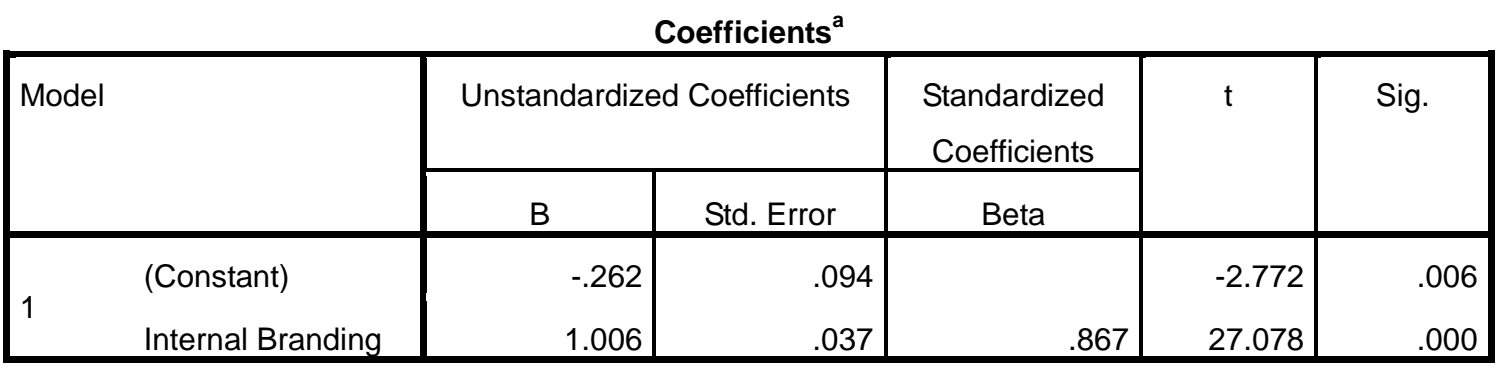

a. Dependent Variable: Brand Commitment

H3: Internal branding (IB) efforts have positive effect on brand supporting behaviour (BSB).

Table 3 shows the regression analysis with dependent variable brand supporting behaviour (BSB) and Internal branding (IB) efforts as independent variables. The regression model is significant $(\mathrm{p}<0.01)$ with adjusted R-square value of 0.506. Internal branding (IB) efforts have a significant $(\mathrm{p}<0.05)$ impact on dependent variable with std coefficient beta values of 0.713 .

Table 3. Regression analysis with dependent variable brand supporting behaviour (BSB) and Internal branding (IB) efforts as independent variables.

\begin{tabular}{|c|c|c|c|c|c|c|}
\hline \multicolumn{7}{|c|}{ Coefficients $^{a}$} \\
\hline \multirow{2}{*}{\multicolumn{2}{|c|}{ Model }} & \multicolumn{2}{|c|}{ Unstandardized Coefficients } & \multirow{2}{*}{$\begin{array}{c}\begin{array}{c}\text { Standardized } \\
\text { Coefficients }\end{array} \\
\text { Beta }\end{array}$} & \multirow[t]{2}{*}{$\mathrm{t}$} & \multirow[t]{2}{*}{ Sig. } \\
\hline & & $B$ & Std. Error & & & \\
\hline \multirow{2}{*}{1} & (Constant) & .902 & .091 & & 9.932 & .000 \\
\hline & Internal Branding & .565 & .036 & .713 & 15.822 & .000 \\
\hline
\end{tabular}

a. Dependent Variable: Brand Supporting Behaviour

H4: Internal Branding (IB),Brand Commitment(BC) and Brand supporting behaviour (BSB) have positive effect on organizational attractiveness (OA).

Table 4 shows the regression analysis with dependent variable Organizational Attractiveness (OA) and Internal branding (IB), Brand commitment (BC) and Brand supporting Behaviour(BSB) as independent variables. The regression model is significant $(\mathrm{p}<0.01)$ with 
adjusted R-square value of 0.811 . Internal branding (IB) and Brand Commitment (BC) have a significant $(\mathrm{p}<0.05)$ impact on dependent variable with std coefficient beta values of 0.395 and 0.580 respectively.

Table 4. Regression analysis with dependent variable organizational attractiveness (OA) and internal branding (IB), Brand commitment (BC) and Brand supporting Behaviour (BSB) as independent variables

Coefficients $^{a}$

\begin{tabular}{|c|c|c|c|c|c|c|}
\hline \multirow{2}{*}{\multicolumn{2}{|c|}{ Model }} & \multicolumn{2}{|c|}{ Unstandardized Coefficients } & \multirow{2}{*}{$\begin{array}{c}\text { Standardized } \\
\text { Coefficients } \\
\text { Beta }\end{array}$} & \multirow[t]{2}{*}{$\mathrm{t}$} & \multirow[t]{2}{*}{ Sig. } \\
\hline & & $\mathrm{B}$ & Std. Error & & & \\
\hline \multirow{4}{*}{1} & (Constant) & -.658 & .147 & & -4.480 & .000 \\
\hline & Internal Branding & .608 & .086 & .395 & 7.051 & .000 \\
\hline & Brand Commitment & .769 & .089 & .580 & 8.642 & .000 \\
\hline & Brand Supporting Behaviour & -.104 & .093 & -.054 & -1.123 & .263 \\
\hline
\end{tabular}

a. Dependent Variable: Org Attract

H5: Brand Allegiance (BA), Brand Citizenship Behaviour (BCB), Brand Endorsement(BE) have positive effect on internal organizational attractiveness (OAin).

Table 5 shows the regression analysis with dependent variable Organizational Attractiveness (OA) and the three factors i.e Brand Allegiance (BA), Brand Citizenship Behaviour(BCB), Brand Endorsement(BE) of Brand supporting behaviour (BSB) as independent variables. The regression model is significant $(\mathrm{p}<0.01)$ with adjusted $\mathrm{R}$-square value of 0.560 . Brand Citizenship Behaviour $(B C B)$ and Brand Allegiance $(B A)$ have a significant $(p<0.05)$ impact on dependent variable with std coefficient beta value of 0.614 and 0.202 respectively.

Table 5. Regression analysis with dependent variable organizational attractiveness (OA) and the three factors i.e Brand Allegiance (BA), Brand Citizenship Behaviour (BCB), Brand Endorsement (BE) of Brand supporting behaviour (BSB) as independent variables.

Coefficients $^{a}$

\begin{tabular}{|c|c|c|c|c|c|c|}
\hline \multirow{2}{*}{\multicolumn{2}{|c|}{ Model }} & \multicolumn{2}{|c|}{ Unstandardized Coefficients } & \multirow{2}{*}{$\begin{array}{c}\text { Standardized } \\
\text { Coefficients } \\
\text { Beta }\end{array}$} & \multirow[t]{2}{*}{$\mathrm{t}$} & \multirow[t]{2}{*}{ Sig. } \\
\hline & & $\mathrm{B}$ & Std. Error & & & \\
\hline \multirow{4}{*}{1} & (Constant) & -.881 & .195 & & -4.520 & .000 \\
\hline & Brand Endorsement & .015 & .107 & .009 & .144 & .886 \\
\hline & Brand Citizenship Behaviour & 1.002 & .090 & .614 & 11.160 & .000 \\
\hline & Brand Allegiance & .329 & .096 & .202 & 3.424 & .001 \\
\hline
\end{tabular}

a. Dependent Variable: Org Attract

H6: Internal Branding (IB).Brand Commitment (BC) and Brand supporting behaviour (BSB) have positive effect on Firm Performance (FP). 
Table 6 shows the regression analysis with dependent variable Firm Performance (FP) and Internal branding (IB), Brand commitment (BC) and Brand supporting Behaviour (BSB) as independent variables. The regression model is significant $(\mathrm{p}<0.01)$ with adjusted R-square value of 0.531. Internal branding (IB) and Brand Supporting Behaviour (BSB) have a significant $(\mathrm{p}<0.05)$ impact on dependent variable with std coefficient beta values of 0.464 and 0.185 respectively.

Table 6. Regression analysis with dependent variable Firm Performance(FP) and Internal branding (IB), Brand commitment (BC) and Brand supporting Behaviour(BSB) as independent variables.

\begin{tabular}{|c|c|c|c|c|c|c|}
\hline \multicolumn{7}{|c|}{ Coefficients $^{\mathrm{a}}$} \\
\hline \multirow[t]{2}{*}{ Model } & \multicolumn{2}{|c|}{ Unstandardized Coefficients } & \multirow{2}{*}{\multicolumn{2}{|c|}{$\frac{\text { Standardized Coefficients }}{\text { Beta }}$}} & \multirow[t]{2}{*}{$t$} & \multirow[t]{2}{*}{ Sig. } \\
\hline & B & Std. Error & & & & \\
\hline (Constant) & -.026 & 186 & & & -.139 & .889 \\
\hline Internal Branding & .574 & .109 & & 464 & 5.253 & .000 \\
\hline Brand Commitment & .143 & .113 & & 134 & 1.268 & .206 \\
\hline Brand Supporting Behaviour & .289 & .117 & & 185 & 2.464 & .014 \\
\hline
\end{tabular}

a. Dependent Variable: Firm Performance

H7: Brand Allegiance (BA), Brand Citizenship Behaviour (BCB), Brand Endorsement (BE) have positive effect on Firm Performance (FP).

Table 7 shows the regression analysis with dependent variable Firm Performance (FP) and the three factors i.e Brand Allegiance (BA), Brand Citizenship Behaviour (BCB), Brand Endorsement (BE) of Brand supporting behaviour (BSB) as independent variables. The regression model is significant $(\mathrm{p}<0.01)$ with adjusted $\mathrm{R}$-square value of 0.475 . Brand Endorsement (BE) and Brand Citizenship Behaviour $(B C B)$ and have a significant $(p<0.05)$ impact on dependent variable with std coefficient beta value of 0.155 and 0.602 respectively.

Table 7. Regression analysis with dependent variable Firm Performance (FP) and the three factors i.e Brand Allegiance (BA), Brand Citizenship Behaviour (BCB), Brand Endorsement (BE) of Brand supporting behaviour (BSB) as independent variables.

\begin{tabular}{|c|c|c|c|c|c|}
\hline \multicolumn{6}{|c|}{ Coefficients $^{a}$} \\
\hline \multirow[t]{2}{*}{ Model } & \multicolumn{2}{|c|}{ Unstandardized Coefficients } & \multirow{2}{*}{$\begin{array}{c}\text { Standardized Coefficients } \\
\text { Beta }\end{array}$} & \multirow[t]{2}{*}{$\mathrm{t}$} & \multirow[t]{2}{*}{ Sig. } \\
\hline & B & Std. Error & & & \\
\hline (Constant) & .118 & .171 & & .690 & .491 \\
\hline Brand Endorsement & .218 & .094 & .155 & 2.311 & .022 \\
\hline Brand Citizenship Behaviour & .790 & .079 & .602 & 10.003 & .000 \\
\hline Brand Allegiance & -.025 & .085 & -.019 & -.291 & .771 \\
\hline
\end{tabular}

a. Dependent Variable: Firm Performance

\section{Managerial Implication}

As this study was conducted within the Asian context particularly in India, this study has 
extended the knowledge beyond the western school of thoughts, validating the application of the concept within different cultural contexts. Essentially, the current study has provided empirical evidence showing the influence of internal branding on employees' brand-supporting behaviour.

Internal Branding (IB) efforts play important role in building brand commitment (BC) as shown by many researchers. The study shows that the Internal Branding (IB) have a significant $(\mathrm{p}<0.05)$ impact on brand commitment $(B C)$. As given by Punjaisri et al, $(2009)$, Internal Branding (IB) efforts have dimensions like training, orientation and briefing. The present study confirms this as in this study also training, orientation and briefing have shown significant association with brand commitment (BC).

For service firms, which are not limited to the IT industry, seeking to ensure the delivery of their brand promise, this study reaffirms the literature (Aurand et al., 2005; Burmann and Zeplin, 2005; Machtiger, 2004) that companies should continuously work on internal communication and training programs to inform and educate staff, as well as reinforce the brand values. This study empirically suggests that internal branding assists management in enhancing employees' brand supporting behaviour (BSB). Furthermore, this study provides empirical reserch that supports the influence of internal branding on the on-brand behaviour of staff (Hankinson, 2002; Thomson et al., 1999). Management are encouraged to communicate with staff and train them constantly about the unique and distinctive brand values, which should be interpreted into daily activities such as brand standards. This will help them to deliver on the brand promise.

Internal Branding (IB) and Brand Commitment (BC) have shown positive effect on organizational attractiveness (OA). Correct internal branding efforts will lead to greater brand commitment and these will lead to higher perception about attractiveness about the organization employees are working for. Brand supporting Behaviour (BSB) as accumulative factor did not have effect on organization attractiveness. But Brand Allegiance (BA) and Brand Citizenship Behaviour (BCB) individually have shown positive effect on internal organizational attractiveness (OA).

Various factors can influence the employee to leave an organisation, or to remain despite being dissatisfied. Employees who have more opportunity to voice dissatisfaction are less likely to leave (Spencer, 1986). An intention to quit is related to job stress, lack of commitment to the employer, and job dissatisfaction (Mellor et al., 2004). Most labor turnover models include a significant affective factors, including organisation commitment, well-being and job satisfaction (Steel et al., 2002; Steel, 2002). Job satisfaction and organisational commitment are many times assumed to influence the decision to leave (Winterton, 2004) but the influence of the corporate brand on this process which is considered to be the most significant affective factor in an organisation, is never considered. Thus brand allegiance (BA) is an important factor which influence organization attractiveness.

Further to this the managers need to understand that external reputation with respect to becoming employer of choice or ranking themselves among best employer studies can also 
help in sustaining superior financial performance over a period of time and create competitive edge over the competitors. In this study also Internal Branding (IB) and Brand supporting behaviour (BSB) have positive effect on Firm Performance (FP). Further Brand Endorsement (BE) and Brand Citizenship Behaviour (BCB) have positive effect on Firm Performance (FP) and managing them do effect the perception about firm performance.

\section{Limitation}

However, it should be acknowledged that this study focused on the IT industry, which is one among several types of industries in the service sector. Some service industries may have a specific nature which is not shared by the others, thereby limiting the generalisability of this study to other service industries.

We would suggest that replications of the relationships tested in this study in different service industries and cultural contexts would help clarifying the conditions for generalisations to theory in other parts of Asia. Moreover, longitudinal data would improve an understanding of the mechanisms influencing different attitudes of employees and their behaviours in delivering the brand performance.

\section{Future Research}

As previously discussed, the findings of this study suggest many more avenues for future research. HR literature have studied many individual aspects associated with employee behaviour, what is lacking is our understanding of how these individual factors relate and impact internal marketing communications. Also, just as emotional bonds are developed between consumers and brands, so too we must strive to understand how strong bonds are developed between employees and brands. Therefore, the study of various areas like personality, values, motivation, emotional intelligence, affective reactions and behavioural responses to employer brands is important to further enrich the internal brand management literature and understand best practice in the service industry.

\section{Conclusion}

The implication of this study to management is that it is significant internal branding includes knowledge from both marketing in terms of internal communication and human resource in terms of training and development programs. Management can deploy internal branding to enhance their employees' brand attitudes and also its distinctiveness to enhance their pride towards the brand to enhance their brand commitment. It is important for management to be informed that training programs to develop and enhance employees' brand-related understanding and skills need to be conducted on regular basis. Management should use communication, daily briefing, group meeting, notice boards and corporate magazine to communicate any brand messages to staff. The importance of effective brand management in realizing financial benefits for the organisation cannot be overstated. With increased interest being given to the financial outcomes, particularly in the services sector, both practitioners and academics alike advocate the important role played by the employee. Brand aligned employees, as demonstrated through employee commitment to the brand and the exhibition of brand citizenship behaviour, has been advocated in the literature to be the result of the 
right internal brand management practices (e.g. internal communication and training).

Clearly managing the employer brand is a complex task, an observation that leads to a final question to both employers and researchers: who should be responsible for managing the employer brand? There is some empirical evidence as to how to promote the employer brand internally (e.g. Hickerman et al., 2005) and how external promotion such as advertisement and sponsorship may also influence employees, but no consensus on the coordination of customer and employer branding. There are various perspectives, including expanding the role of marketing or a greater understanding of branding issues among HR professionals (e.g. Martin and Beaumont, 2003). Others argue for a new role, that of reputation manager (e.g. Davieset al., 2002), responsible for co-ordinating internal and external branding and to all stakeholders. Certainly there is value in managing the employer brand and a potential danger if no function accepts or is given responsibility for it.

\section{References}

Ambler, T., \& Barrow, S. (1996). The employer brand. Journal of Brand Management, 4(3), 185-206.

Backhaus, K., \& Tikoo, S. (2004). Conceptualizing and Researching Employer Branding, Career Development International, 9(4-5), 505-510.

Barney, J. (1991). Firm resources and sustained competitive advantage. Journal of Management, 17(1), 99-120.

Ballou, B., Godwin, N. H., \& Shortridge, R. T. (2003). Firm value and employee attitudes on workplace quality. Accounting Horizons, 17(4), 329-341.

Beckett-Camarata, E. J., Camarata, M. R., \& Barker, R. T. (1998). Integrating internal and external customer relationships through relationship management: A strategic response to a changing global environment. Journal of Business Research, 41(1), 71-81.

Bergstrom, A., Blumenthal, D., \& Crothers, S. (2002). Why Internal Branding Matters: The Case of Saab. Corporate Reputation Review, 5(2/3), 133-142.

Berthon, Ewing, M. J., \& Hah, L. L. (2005). Captivating Company: Dimensions of Attractiveness in Employer Branding. International Journal of Advertising, 24(2), 151-172.

Bergstrom, A., Blumenthal, D., \& Crothers, S. (2002). Why internal branding matters: the case of Saab. Journal of Communication Management, 5(2/3), 133-142.

Berry, L. L. (2000). Cultivating service brand equity. Journal of the Academy of Marketing Science, 28(1), 128-37.

Bhatnagar \& Srivastava. (2010). Employer brand for talent acquisition: an exploration towards its measurement, vision. The Journal of Business Perspective, 14(1 \& 2).

Bloemer, J., \& Odekerken-Schr ö der, G. (2006). The role of employee relationship proneness in creating employee loyalty. International Journal of Bank Marketing, 24(4), 252 - 264. 


\section{I Macrothink}

International Journal of Human Resource Studies

ISSN 2162-3058

2017, Vol. 7, No. 2

Boone, M. (2000). The importance of internal branding. Sales \& Marketing Management, 152(9), 36-8.

Buss, D. (2002). In good company. Brandweek, 20, 28-30.

Burmann, C., \& Zeplin, S. (2005). Building brand commitment: a behavioural approach to internal brand building. Journal of Brand Management, 12(4), 279-300.

Burmann, C., Zeplin, S., \& Riley, N. (2009). Key determinants of internal brand management success. Journal of Brand Management, 16(4), 264-284.

Cable, D. M., \& Graham, M. (2000). The determinants of organizational reputation: a job search perspective. Journal of Organizational Behavior, 21, 929-47.

Cable, D. M., \& Turban, D. B. (2001). Establishing the dimensions, sources and value of job seekers' employer knowledge during recruitment. In G. R. Ferris (Ed.), Research in personnel and human resources management (pp. 115-163). New York: Elsevier Science.

Castro, C. B., Armario, E. M., \& Sanchez del Rio, M. E. (2005). Consequences of market orientation for customers and employees. European Journal of Marketing, 39(5/6), 646-75.

Collins, C. J., \& Stevens, C. K. (2002). The relationship between early recruitment related activities and the application decisions of new labor-market entrants: a brand equity approach to recruitment. Journal of Applied Psychology, 87(6), 1121-1133.

Corace, C. J. (2007). Engagement. Enrolling the quiet majority. Organizational Development Journal, 25(2), 171-5.

Davies, G. J., Chun, R., Da Silva, R., \& Roper, R. (2004). A corporate character scale to assess employee and customer views of organisation reputation. Corporate Reputation Review, 7(2), 125-46.

De Chenatony, L., \& McDonald, M. (2003). Creating Powerful Brands in Consumer, Service and Industrial Markets, 3rd edition, Butterworth-Heinemann, Oxford.

Deluga, R. J. (1994). Supervisor trust building, leader member exchange and organizational citizenship behaviour. Journal of Occupational and Organizational Psychology, 67(4), 315-327.

Drake, S. M., Gulman, M. J., \& Roberts, S. M. (2005). Light their Fire, Dearborn, Chicago, IL.

Ewing, M. T., Pitt, L.F., de Bussy, N.M. \& Berthon, P. (2002), Employment branding in the knowledge economy. International Journal of Advertising, 21(1), 3-22.

Eberl, M., \& Schwaiger, M. (2005). Corporate reputation: disentangling the effects on financial performance. European Journal of Marketing, 39(7/8), 838.

Edwards, M. R. (2010). An integrative review of employer branding and OB theory. Personnel Review, 39(1), 5-23. 


\section{$\triangle$ Macrothink}

International Journal of Human Resource Studies

ISSN 2162-3058

2017, Vol. 7, No. 2

Fombrun, C., \& Shanley, M. (1990). What's in a name? Reputation building and corporate strategy. Academy of Management Journal, 33(2), 233-258.

Foster, C., Punjaisri, K., \& Cheng, R. (2010). Exploring the relationship between corporate, internal and employer branding. Journal of Product \& Brand Management, 19/6, 401-409.

Fulmer, I. S., Gerhart, B., \& Scott, K.S. (2003), "Are the100 best better? An empirical investigation of the relationship between being a great place to work and firm performance", Personnel Psychology, Vol. 56, pp. 965-93.

Gatewood, R. D., Gowan, M. A., \& Lautenschlager, G. J. (1993). Corporate image, recruitment, image and initial job choice decisions. Academy of Management Journal, 36(2), 414-427.

Gilly, M. C., \& Wolfinbarger, M. (1998). Advertising's internal audience. Journal of Marketing, 62(1), 69-88.

Hatch, M. J., \& Schultz, M. (2009). Of bricks and brands: From corporate to enterprise branding. Organizational Dynamics, 38(2), 117-130.

Henkel, S., Tomczak, T., Heitmann, M., \& Herrmann, A. (2007). Managing brand consistent employee behavior: Relevance and managerial control of behavioural branding. Journal of Product and Brand Management, 16(5), 310 - 320.

Herington, C., Johnson, L.W., \& Scott, D. (2009). Firm-employee strength - a conceptual model. Journal of Business Research, 62(11), 1062-107.

Highhouse, S., Zickar, M. J., Thorsteinson, T. J., Stierwalt,S. L., \& Slaughter, J. E. (1999). Assessing company employment image: An example in the fast food industry. Personnel Psychology, 52, 151-172.

Jurgensen, C. E. (1978). Job preferences (what makes a job good or bad?). Journal of Applied Psychology, 63(3), 267-276.

Joyce, K. E. (2003). Lessons for employers from Fortune's "100 Best". Business Horizons, 46(2), 77-84.

Judge, T. A., Bono, J. E., Thoresen, C. J., Patton, G. K. (2001). The Job satisfaction-job performance relationship: A qualitative and quantities review. Psychological Bulletin, 127, 376-407.

Kimpakorn, N., \& Tocquer, G. (2009). Employees' Commitment to Brands in the Service Sector: Luxury Hotel Chains in Thailand. Brand Management, 16(8), 532-544.

King, C., \& Grace, D. (2005 ). Exploring the role of employees in the delivery of the brand: A case study approach. Qualitative Market Research, 8(3), 277 - 295.

King, C., \& Grace, D. (2012). Examining the antecedents of positive employee brand-related attitudes and behaviours. European Journal of Marketing, 46(3/4), 469-488.

Kirnan, J. P., Farley, J. A., \& Geisinger, K. F. (1989). The relationship between recruiting 
source, applicant quality and hire performance: An analysis by sex, ethnicity and age. Personnel Psychology, 42(2), 293 - 308.

Knox, S., \& Freeman, C. (2006). Measuring and managing employer brand image in the service industry. Journal of Marketing Management, 22(7/8), 695 - 716.

Kotler, P. (1991). Marketing Management: Analysis, Planning and Control, Prentice-Hall, Englewood Cliffs.

Lievens, F., \& Highhouse, S. (2003). The relation of instrumental and symbolic attributes to a company's attractiveness as an employer. Personnel Psychology, 56, 75-101.

Lievens, E., Hoye Greet, V., \& Anseep, E. (2007). Organizational Identity and Employer Image: Towards a Unifying Framework. British Joumal of MüTuigemiínt, 18(1), S45-S59.

Maxwell, R., \& Knox, S. (2009). Motivating employees to "live the brand": A comparative case study of employer brand attractiveness within the firm. Journal of Marketing Management, 25(9/10), 893-907.

Mitchell, C. (2002). Selling the brand inside. Harvard Business Review, 80(1), 99-105.

Miles, S. J., \& Mangold, G. (2004). A conceptualization of the employee branding process. Journal of Relationship Marketing, 3(2/3), 65-87.

Morehart, K. K. (2001). How to create an employee referral program that really works. $H R$ Focus, 78(1), 3.

Morhart , F. M., Herzog, W., \& Tomczak, T. (2009). Brand-specific leadership: Turning employees into brand champions. Journal of Marketing, 73, $122-142$.

Mosley, R. W. (2007). Customer experience, organisational culture and the employer brand. Brand Management, 15(2), 123-34.

Papasolomou, I., \& Vrontis, D. (2006b). Using internal marketing to ignite the corporate brand: the case of the UK retail bank industry. Journal of Brand Management, 14(1/2), 177.

Punjaisri, K., \& Wilson, A. (2007). The role of internal branding in the delivery of employee brand promise. Journal of Brand Management, 15(1), 57-70.

Punjaisri, K., Evanschitzky, H., \& Wilson, A. (2009). Internal branding: an enabler of employees' brand supporting behaviours. Journal of Service Management, 20(2), 209-26.

Ramlall, S. (2004). A review of employee motivation theories and their implications for employee retention within organizations. Journal of American Academy of Business, 5(1/2), $52-63$.

Robert, P. W., \& Dowling, G. R. (2002). Corporate reputation and sustained superior financial performance. Strategic Management Journal, 23, 1077-1093.

Romero, E. J. (2004). Are the great places to work also great performers? Academy of Management Executive, 18(2), 150-152. 


\section{Macrothink}

International Journal of Human Resource Studies

ISSN 2162-3058 2017, Vol. 7, No. 2

Rynes, S. L. (1991). Recruitment, job choice, and post-hire consequences. In M. D. Dunnette \& L. M. Hough (Eds.), Handbook of industrial and organizational psychology (2nd ed.. Vol. 2, pp. 399-444). Palo Alto, CA: Consulting Psychologists Press.

Schiffman, L., Bednall, D., Cowley, E., O’Cass, A., Watson, J., \& Kanuk, L. (2001), Consumer Behaviour, Prentice Hall, Frenchs Forest.

Shinnar, R. S., Young, C. A., \& Meana, M. (2004). The motivations for and outcomes of employee referrals. Journal of Business and Psychology, 19(2), 271.

Snell, S. A., \& Dean Jr, J. W. (1992). Integrated manufacturing and human resource management: A human capital perspective. Academy of Management Journal, 35(3), 467-504.

Soutar, G. N., \& Clarke, A. (1983). Examining business students' career preferences: a perceptual space approach. Journal of Vocational Behavior, 23(1), 11-21.

Tosti, D. T., \& Stotz, R. D. (2001). Brand: Building your brand from the inside out. Marketing Management, 10(2), 28 - 33.

Williams, C. R., Labig, C. E. J., \& Stone, T. H. (1993). Recruitment sources and post-hire outcomes for job applicants and new hires: A test of two hypo theses. Journal of Applied Psychology, 78(2), $163-173$.

Van Hoye, G., \& Lievens, F. (2005). Recruitment-related information sources and organizational attractiveness: Can something be done negative publicity? International Journal of Selection and Assessment, 13, 179-187.

Van Hoye, G. (2008). Nursing recruitment: Relationship between perceived employer image and nursing employees' recommendations. Journal of Advanced Nursing, 63, 366-375.

Wallace, E., \& de Chernatony, L. (2009). Service employee performance: its components and antecedents. Journal of Relationship Marketing, 8(2), 82-102.

Zeithaml, V. A., Berry, L. L., \& Parasuraman, A. (1996). The behavioural consequences of service quality. Journal of Marketing, 60(2), 31 - 46.

\section{Copyright Disclaimer}

Copyright for this article is retained by the author(s), with first publication rights granted to the journal.

This is an open-access article distributed under the terms and conditions of the Creative Commons Attribution license (http://creativecommons.org/licenses/by/4.0/). 